\title{
Access to Dental-Care Services in Jazan, Saudi Arabia: A Scoping Review
}

\author{
Mosa A. Shubayr ${ }^{a, b}$ Estie Kruger ${ }^{c}$ Marc Tennant ${ }^{c}$ \\ aSchool of Human Sciences, The University of Western Australia, Nedlands, WA, Australia; ${ }^{\text {b}}$ Department of \\ Preventive Dental Sciences, College of Dentistry, Jazan University, Jazan, Kingdom of Saudi Arabia; \\ 'International Research Collaborative, Oral Health and Equity, School of Human Sciences, The University of \\ Western Australia, Nedlands, WA, Australia
}

\section{Keywords}

Oral health care · Dental care services · Dental accessibility · Jazan · Saudi Arabia

\section{Abstract}

Introduction: The construct of dental access adopted in this study uses the following 4 main dimensions: opportunity for access, realized access or utilization, equity, and outcome. Aims: The principal aims of this study were to identify various indicators used in the literature to measure each dimension of access in Saudi Arabia, to summarize and map the range of existing research with policy implications, to identify gaps in research, and to consider implications for future research. Methods: This scoping review was conducted using the PubMed, Scopus, and Google Scholar databases, as well as manually. Additional relevant publications were identified by manually searching the reference list of the included studies. Data were extracted based on the 4 dimensions of the access framework. Results: The search strategy yielded 230 studies, of which 16 were included after full-text revision. Of the 4 domains, the most explored and in all included studies were realized access, but no differentiation was made by the authors between initial utilization and con- karger@karger.com www.karger.com/sjh

Karger"
(C) 2021 The Author(s)

Published by S. Karger AG, Basel

This is an Open Access article licensed under the Creative Common Attribution-NonCommercial-4.0 International License (CC BY-NC) (http://www.karger.com/Services/OpenAccessLicense), applicable to the online version of the article only. Usage and distribution for commercial purposes requires written permission. tinued engagement. Conclusions: An overview of different policy suggestions has been provided. In particular, we recommend making better use of teledentistry, improving referral services between dentists and physicians, and offering more education on dental prevention in schools' health-service sites.

(C) 2021 The Author(s)

Published by S. Karger AG, Basel

\section{Introduction}

Globally, dental caries occurs ten times higher than other common oral diseases [1]. The prevalence in underdeveloped or developing countries is increasing over time, which is the opposite trend to the prevalence of caries in developed countries [2]. Oral health issues exist for many reasons, such as poor diet, food insecurity, income inequality, and low levels of health literacy and education [3]. However, even though the government of the Kingdom of Saudi Arabia (KSA) pays for all basic dental care, in the last decade, the prevalence of caries has increased dramatically in the KSA, from 68 to $96 \%$ in children, adults, and older individuals [4-6]. Recent studies suggest that the lack of dental care may also correlate with

Correspondence to:

Mosa A. Shubayr, mosa.shubayr@ research.uwa.edu.au 
systemic diseases such as cardiovascular disease and diabetes $[7,8]$. These outcomes could be related to access to dental health services [9] and low utilization of dental services in the KSA $[10,11]$.

Based on a 2019 survey on patient's satisfaction with the Saudi Ministry of Health $(\mathrm{MOH})$ services, about $72.2 \%$ of the patients indicated their satisfaction. However, the Jazan region scored the lowest patient satisfaction compared to other regions [12]. Also, Jazan recorded a high prevalence of dental caries because of inadequate oral-hygiene practices, high consumption of soft drinks, and high sugar consumption, which is considered to be widespread in Saudi Arabia [13]. The high rate of dental caries could be due to not being seen by a dentist consistently [13]. A study published in 2021 found that there are many issues encountered with dental-care services in Jazan such as the location of services and the lack of dental providers which could cause low dental-care accessibility [14].

Access to health care is defined as the "timely use of personal health services to achieve the best possible health outcomes" [15]. Access, which is often used interchangeably with coverage or utilization [16], is concerned with the degree to which individuals or groups are able to receive health service when needed [15]. Understanding oral health care underscores both the availability and use of care [10]. In order to be able to evaluate the accessibility of dental health services, this study uses 3 key indicators for accessibility, including utilization, outcomes, and barriers to accessing dental care [15]. The first indicator, utilization of dental health services, is defined as the percentage of the population who access dental services over a specified period of time [17]. A conceptual definition of dental-care access is important in order to select indicators for policy purposes [18]. The accessibility influence by many factors related to both service provision and service usage [16]. According to Healthy People 2020, some barriers can limit individuals from utilizing oral preventive treatments and interventions. Such barriers may include lack of accessibility to dental services, anxiety about dental procedures, lack of awareness of oral health-care needs, and limited finances [19]. Measuring the outcome of healthcare is a complementary approach to accessibility measurement [15]. In oral health, some studies used different indicators to measure the oral health status outcome such as dental caries and periodontal issues [20].

Since the $\mathrm{MOH}$ in Saudi Arabia has a similar healthcare system across the country [21], the review included many studies which were conducted in other regions within the country. This scoping review was intended to identify various indicators used in the literature to measure each dimension in Saudi Arabia, to summarize and map the range of existing research with policy implications, to identify gaps in research, and to consider implications for future research.

\section{Methods}

Based on the methodological framework for conducting scoping reviews proposed by Arksey and O'Malley [22], we conducted the review process as follows: (1) identifying the research question; (2) searching for relevant studies; (3) selecting studies based on pre-defined inclusion criteria; (4) extracting data; and (5) collating, summarizing, and reporting the results. This approach brings together disparate studies with different study designs, target populations, study settings, and, more importantly, indicators for each domain of dental access, which might have been used.

The search strategy focused on peer-reviewed publications in electronic databases such as Medline via PubMed, Scopus, and Google Scholar between 2000 and 2021 to ensure relevancy to the current practice, and only studies published in English were included. Additional relevant publications were identified manually searching the references of the included studies.

The theoretical framework for access to dental services is based on that proposed by 2 studies [18, 23]. Similarly, to Harris [18], the review used 4 dimensions of dental access to inform the selection of indicators as follows: opportunity for access, realized access or utilization, equity, and outcomes. The dimensions and conceptual definitions of each guided the extraction of data from the selected studies. The selection of indicators to measure and evaluate dental access is presented in Table 1 to reflect the variety of indicators used in different studies. The following data were also extracted from each study: city/region, study aims, participants, design and methods, and key policy recommendations.

\section{Results}

\section{Descriptive Summary of Articles}

A total of 230 articles were identified through database searches, with 215 remaining in the sample after deletion of duplicates. The Title and Abstract of the identified studies were independently screened by 2 reviewers using the inclusion criteria followed by full-text retrieval. One hundred and eighty-nine articles were excluded after title and abstract screening. Twenty-six articles were selected for full-text review, and 9 were excluded during this phase. Disagreements between reviewers were resolved following discussions. Sixteen articles were selected that met the inclusion criteria. The process of study selection is graphically represented in Figure 1.

Table 2 provides key characteristics of the included studies. The sample size among the studies varied from
Shubayr/Kruger/Tennant 
Fig. 1. PRISMA flow diagram. The flow chart of PRIMSA details the study search and selection process applied during the overview.

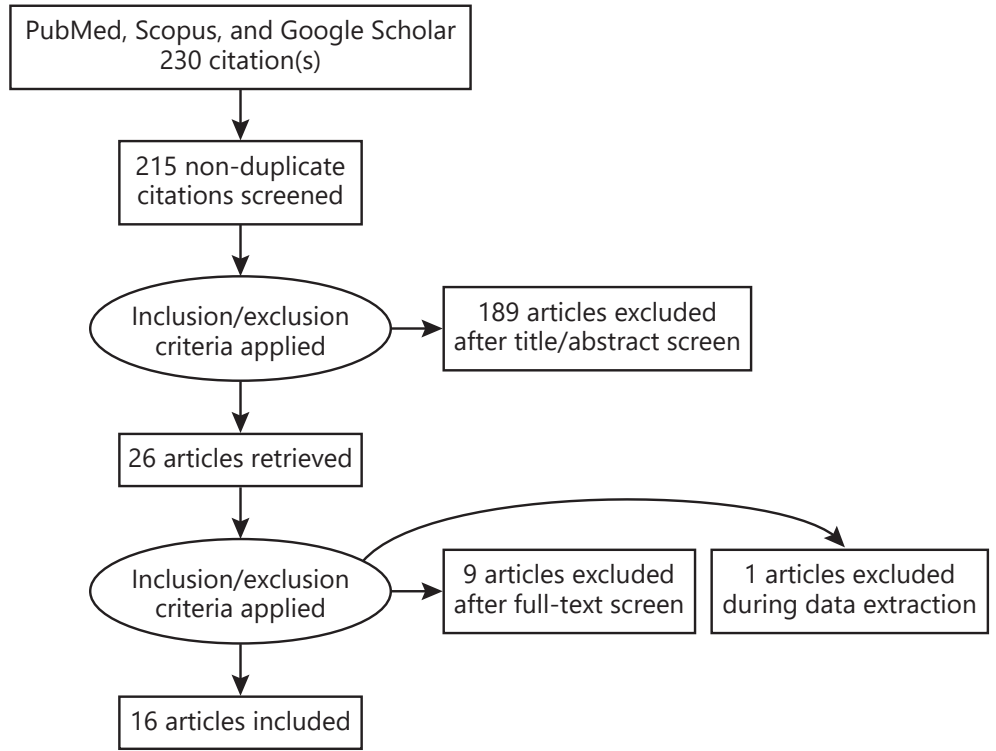

Table 1. Domains of dental access and relevant indicators used in this study

\begin{tabular}{|c|c|}
\hline Domain and conceptual definition & Relevant indices \\
\hline $\begin{array}{l}\text { Opportunity for access } \\
\text { Whether individuals or groups are able to obtain and make use of the } \\
\text { needed dental care }\end{array}$ & $\begin{array}{l}\text { Reported barrier to health-care access } \\
\text { Dentist- and facility-related } \\
\text { Insurance coverage } \\
\text { Transportation }\end{array}$ \\
\hline $\begin{array}{l}\text { Realized access } \\
\text { Initial utilization: whether the individuals or groups make contact with } \\
\text { the dental service for any type of care (emergency, therapeutic, and/or } \\
\text { preventive) } \\
\text { Continued engagement: whether the individuals or groups receive } \\
\text { nonsymptomatic care }\end{array}$ & $\begin{array}{l}\text { Initial utilization } \\
\text { Proportion of the population who had visited the dentist in the last } 12 \\
\text { months } \\
\text { Routine dental visits during the last } 12 \text { months } \\
\text { Continued engagement } \\
\text { Reason for the last visit to the dentist expressed as a proportion } \\
\text { visiting the dentist for checkup/routine care*/emergency treatment }\end{array}$ \\
\hline $\begin{array}{l}\text { Equitable access } \\
\text { Where demographic and need variables account for most of the } \\
\text { variance in utilization }\end{array}$ & Horizontal equity index \\
\hline $\begin{array}{l}\text { Outcome of care } \\
\text { Whether individuals and groups benefit from their encounter with the } \\
\text { service }\end{array}$ & Patient-reported outcome of treatment \\
\hline
\end{tabular}

Adapted from Harris [18].

52 to 1,397 participants. All age-groups were considered in the included studies; however, the majority of the studies focused on school-aged children, mostly males. Nonprobability sampling methods such as convenience sampling and multistage random sampling techniques were frequently used, while some studies did not report the sampling methods adopted in the studies. None reported their sample size calculations, making the generalizability of studies' findings difficult. Different studies reported on the realized access indicators, using a variety of indicators that made comparison between studies complex (Table 2). 
Table 2. Characteristics of included studies

\begin{tabular}{|c|c|c|c|c|c|}
\hline Study & City/region & Study's aim & Participants/setting $(N)$ & $\begin{array}{l}\text { Sample/sampling } \\
\text { methods }\end{array}$ & Design/methods \\
\hline Al-Ansari [30] & $\begin{array}{l}\text { Dammam city/ } \\
\text { Eastern Region }\end{array}$ & $\begin{array}{l}\text { Assess the level of awareness } \\
\text { and utilization of methods to } \\
\text { prevent oral diseases }\end{array}$ & 17-71 years old/UDC (1) & $\begin{array}{l}\text { 234/convenience } \\
\text { sample }\end{array}$ & $\begin{array}{l}\text { Quantitative, cross-sectional/ } \\
\text { self-administered } \\
\text { questionnaire }\end{array}$ \\
\hline $\begin{array}{l}\text { Al-Jaber and } \\
\text { Da'a [28] }\end{array}$ & Riyadh city & $\begin{array}{l}\text { Identify challenges faced by } \\
\text { patients seeking oral care in } \\
\text { PHC centers and assess } \\
\text { determinants of demand for } \\
\text { oral care services }\end{array}$ & $\begin{array}{l}\text { Adult patients } \geq 18 \text { years } \\
\text { old/PHC ( } 2)\end{array}$ & $\begin{array}{l}\text { 300/convenience } \\
\text { sample }\end{array}$ & $\begin{array}{l}\text { Quantitative, cross-sectional } \\
\text { study/self-administered } \\
\text { questionnaire }\end{array}$ \\
\hline Al-Shehri [39] & $\begin{array}{l}\text { Riyadh and } \\
\text { Al-Hfouf }\end{array}$ & $\begin{array}{l}\text { Assessment of difficulties in } \\
\text { accessing dental care and to } \\
\text { identify barriers to dental care }\end{array}$ & $\begin{array}{l}\text { All ages and persons with } \\
\text { disabilities }\end{array}$ & $\begin{array}{l}119 \text { caregivers of } \\
\text { persons with } \\
\text { disabilities/NA }\end{array}$ & $\begin{array}{l}\text { Quantitative, cross-sectional/ } \\
\text { self-administered } \\
\text { questionnaire }\end{array}$ \\
\hline Al-Sinaidi [45] & Riyadh/ & $\begin{array}{l}\text { Assess the periodontal health } \\
\text { status and oral hygiene } \\
\text { practices of visually impaired }\end{array}$ & 18-87 years/HB (1) & $52 / \mathrm{NA}$ & $\begin{array}{l}\text { Quantitative, cross-sectional } \\
\text { interview and clinical oral } \\
\text { examination }\end{array}$ \\
\hline $\begin{array}{l}\text { Al Agili and } \\
\text { Farsi [10] }\end{array}$ & Jeddah city & $\begin{array}{l}\text { Assessment of predicting } \\
\text { factors that influence } \\
\text { utilization of oral health } \\
\text { services }\end{array}$ & $\begin{array}{l}\text { 9-14 years old, male and } \\
\text { females'/SB }\end{array}$ & $1,397 / \mathrm{NA}$ & $\begin{array}{l}\text { Quantitative, cross-sectional/ } \\
\text { parents-administered } \\
\text { questionnaire and clinical } \\
\text { examination }\end{array}$ \\
\hline $\begin{array}{l}\text { Al Dalbahi } \\
\text { et al. [31] }\end{array}$ & Riyadh city & $\begin{array}{l}\text { Assessment of problems that } \\
\text { affect the general public in } \\
\text { accessing dental care }\end{array}$ & $\begin{array}{l}\text { Adults aged } \geq 18 \text { years/ } \\
\text { online }\end{array}$ & $\begin{array}{l}\text { 600/convenience } \\
\text { sampling }\end{array}$ & $\begin{array}{l}\text { Quantitative, cross-sectional/ } \\
\text { self-administered, closed- } \\
\text { ended }\end{array}$ \\
\hline Al Johara [26] & Riyadh city & $\begin{array}{l}\text { Determine factors affecting } \\
\text { utilization of dental health } \\
\text { services }\end{array}$ & $\begin{array}{l}\text { 12-15 years old, females/ } \\
\text { SB (12) }\end{array}$ & $531 / \mathrm{NA}$ & $\begin{array}{l}\text { Quantitative, cross-sectional/ } \\
\text { self-administered } \\
\text { questionnaire }\end{array}$ \\
\hline $\begin{array}{l}\text { Almutlaqah } \\
\text { et al. [29] }\end{array}$ & Abha city & $\begin{array}{l}\text { Investigate factors that } \\
\text { influence dental access }\end{array}$ & $\begin{array}{l}\text { Adults aged } \geq 18 \text { years/ } \\
\text { major gathering centers }\end{array}$ & $\begin{array}{l}\text { 499/convenience } \\
\text { sampling }\end{array}$ & $\begin{array}{l}\text { Quantitative, cross-sectional/ } \\
\text { self- administered } \\
\text { questionnaire }\end{array}$ \\
\hline $\begin{array}{l}\text { Ali Alzahrani } \\
{[35]}\end{array}$ & $\begin{array}{l}\text { Albaha, } \\
\text { Alatawelah, and } \\
\text { Alaquiq regions in } \\
\text { Albaha province }\end{array}$ & $\begin{array}{l}\text { Examine the oral health status } \\
\text { and attitudes of Saudi } \\
\text { adolescents }\end{array}$ & $\begin{array}{l}12-15 \text { years old, males/ } \\
\text { SB (3) }\end{array}$ & $\begin{array}{l}\text { 249/randomized } \\
\text { sampling technique }\end{array}$ & $\begin{array}{l}\text { Quantitative, cross-sectional/ } \\
\text { questionnaire and clinical } \\
\text { examination }\end{array}$ \\
\hline $\begin{array}{l}\text { Bahannan } \\
\text { et al. [40] }\end{array}$ & $\begin{array}{l}\text { Al-Khomrah } \\
\text { district in South } \\
\text { Jeddah }\end{array}$ & $\begin{array}{l}\text { Assess the prevalence and } \\
\text { associated factors of dental } \\
\text { caries and periodontal diseases }\end{array}$ & $\begin{array}{l}\text { 14-19 years old, males } \\
\text { and females/SB(NA) }\end{array}$ & $734 / \mathrm{NA}$ & $\begin{array}{l}\text { Quantitative and qualitative, } \\
\text { cross-sectional/questionnaire } \\
\text { and clinical examination }\end{array}$ \\
\hline $\begin{array}{l}\text { Hamasha } \\
\text { et al. [9] }\end{array}$ & Riyadh & $\begin{array}{l}\text { Evaluate barriers associated } \\
\text { with access and utilization of } \\
\text { dental services }\end{array}$ & $\begin{array}{l}65 \text { years and older/NH } \\
\text { and } \mathrm{CD}\end{array}$ & $\begin{array}{l}\text { 350/systematic } \\
\text { random sampling }\end{array}$ & $\begin{array}{l}\text { Quantitative and qualitative, } \\
\text { cross-sectional/questionnaires } \\
\text { and interviews }\end{array}$ \\
\hline $\begin{array}{l}\text { Mahrous } \\
\text { et al. [66] }\end{array}$ & $\begin{array}{l}\text { Almadinah } \\
\text { Almunawwarah }\end{array}$ & $\begin{array}{l}\text { Report on the caries status and } \\
\text { dental service utilization }\end{array}$ & 6 and 12 years old/SB (4) & $\begin{array}{l}\text { 330/simple random } \\
\text { sampling }\end{array}$ & $\begin{array}{l}\text { Quantitative and qualitative, } \\
\text { cross-sectional/questionnaire } \\
\text { and a clinical examination }\end{array}$ \\
\hline Nazir [33] & $\begin{array}{l}\text { Dhahran, } \\
\text { Al- Khobar, and } \\
\text { Dammam }\end{array}$ & $\begin{array}{l}\text { Evaluate factors associated with } \\
\text { routine dental attendance }\end{array}$ & $\begin{array}{l}16-18 \text { years, males/SB } \\
\text { (NA) }\end{array}$ & $\begin{array}{l}\text { 586/multistage } \\
\text { random sampling }\end{array}$ & Quantitative, cross-sectional \\
\hline $\begin{array}{l}\text { Quadri } \\
\text { et al. [11] }\end{array}$ & Jazan/Jazan region & $\begin{array}{l}\text { Assess factors that influence } \\
\text { dental service utilization }\end{array}$ & $\begin{array}{l}\text { All age-groups, male and } \\
\text { females/PHC (5) and } \\
\text { UDC (1) }\end{array}$ & $(395) / \mathrm{NA}$ & $\begin{array}{l}\text { Quantitative, cross-sectional/ } \\
\text { self-administered } \\
\text { questionnaire }\end{array}$ \\
\hline $\begin{array}{l}\text { Tikare } \\
\text { et al. [25] }\end{array}$ & Abha and Khamis & $\begin{array}{l}\text { Assess effectiveness of school } \\
\text { oral health screening and } \\
\text { factors affecting dental } \\
\text { attendance }\end{array}$ & 6-12 year, females/SB (4) & $\begin{array}{l}\text { 1,035/multistage } \\
\text { cluster random } \\
\text { sampling }\end{array}$ & Quantitative, cross-sectional \\
\hline $\begin{array}{l}\text { Togoo } \\
\text { et al. [24] }\end{array}$ & $\begin{array}{l}\text { Rijal Alma'a, } \\
\text { Asser province }\end{array}$ & $\begin{array}{l}\text { Assessment of oral health } \\
\text { knowledge and practices in a } \\
\text { rural area }\end{array}$ & $\begin{array}{l}\text { 9-12 years old, males/SB } \\
(10)\end{array}$ & $\begin{array}{l}\text { 917/stratified } \\
\text { random sampling }\end{array}$ & $\begin{array}{l}\text { Quantitative, cross-sectional/ } \\
\text { self-administered } \\
\text { questionnaire }\end{array}$ \\
\hline
\end{tabular}

NA, nonavailable; PHC, primary health care center; HB, hospital based; UDC, university dental clinic; SB, school based. 


\section{Opportunity for Access}

Only 3 studies out of 8 that considered school-aged children and adolescents reported the indicators they utilized related to the domain of opportunity for dental access. One study reported that $17.3 \%$ of the participants were not able to access care because no clinic was available near their school or home as reported by the children themselves [24]. In 2 other studies where the questionnaire was filled out by parents, the most important barrier they mentioned was a health literacy of $82.3 \%$, while nearly $23 \%$ reported financial issues, transportation, and long waiting times [10]. For nearly $41 \%$ of parents, lack of time was the main reason for not bringing their children to the dentist when referred [25]. We recorded various barriers as reported by caregivers/parents or participants directly (Table 3 ).

The location of dental clinics was also one of the most discouraging factors mentioned [26]. Utilization of dental services was lower in rural areas than in urban areas [27], which was considered a risk factor affecting oral health status [26]. These studies presented some barriers that limit children from utilizing dental services, such as fear of the dentist and lack of parental encouragement [24]. The quality of dental care was found to be one of the most encouraging factors in actually utilizing dental services.

Among adults and the elderly, several studies in Saudi Arabia found that cost was a barrier for them utilizing dental services [28-30]. Being unable to afford private clinics because of the high cost is one of the most common barriers to seeking dental care, as well as shortages of providers, long waiting times, and limited treatment choices in public clinics $[10,29]$. Other barriers were lack of a perceived dental need, transportation $[9,29]$, lack of reminder messages [31], fear of dentists, distance from their residence, and the presence of a disability [9]. Educated participants that practiced oral hygiene measures regularly were more likely to visit dental clinics for routine checkups [11,32].

\section{Realized Access}

Dental pain requires patients to seek immediate access to dental care and better quality of services, which increases their likelihood of seeking dental treatment in a private practice, where they can be seen immediately [33]; Nazir [33] found that most patients $(68.0 \%)$ visited private dental clinics and that $70.4 \%$ visited a dental office because of tooth pain. Unfortunately, many Saudis of all ages only seek access to a dentist because of dental pain (Table 3).

Access to Dental-Care Services in Jazan
According to some studies, approximately a quarter of all children have never visited a dentist in their life. However, about a third of children need dental care and have been unable to get it [10]. Almutlaqah et al. [29] found that more than half of the participants used dental services and that their main reason for dental visits was emergencies; they had visited the dentist in the past year. AAl Johra found that three-quarters of the participants had visited the dentist more than once during the last 2 years [26]. However, El Bcheraoui et al. [32] with $>10,735$ students found that almost $87 \%$ had not visited a dentist in the last year. Also, the percentage of children with no previous visits to a dentist was high (38.3\%) [34]. Another study found that most of the children participating went to the dentist for illness-related issues rather than preventative care $[10,35,36]$. Onethird of the children visit a dentist only when they have pain [36]. Among schoolchildren, factors that led to not using dental services included parental attitudes and anxiety, including "lack of time" and "logistic problems" $[25,35]$.

Among the elderly, only $37.4 \%$ have proper access to dental services [9]. A study by Al-Jaber and Da'ar [28] that included adults found that almost three-fifths of patients visited dentists once a year, $22 \%$ had visited a dentist in the previous 2 years, and $14 \%$ had gone $>2$ years without visiting a dentist, and most of them had visited a dentist once. Among these study participants, the most common reason to visit the dentist was for tooth or gum problems [28].

Based on the literature review, patients with special needs are more likely to have poor oral hygiene and oral diseases for numerous reasons, including limited dentalcare access [37]. Aljabri et al. [38] reported that $15.5 \%$ of individuals with special needs have an issue with accessibility to dental services [39].

\section{Equitable Access}

Four of the 16 studies assessed equity in dental access (Table 3). Three studies reported the existence of education and income-related inequality among adults and the elderly $[10,11,29]$. Only one study used regression models to account for need and socioeconomic background in service utilization [10]. Individuals or families without adequate financial resources to access appropriate dental care often experience poor oral health. For example, there are more cases of tooth decay in children from deprived backgrounds than in children from affluent backgrounds [40]. Poor and disadvantaged population groups consistently have a higher burden of oral disease and lower ac- 


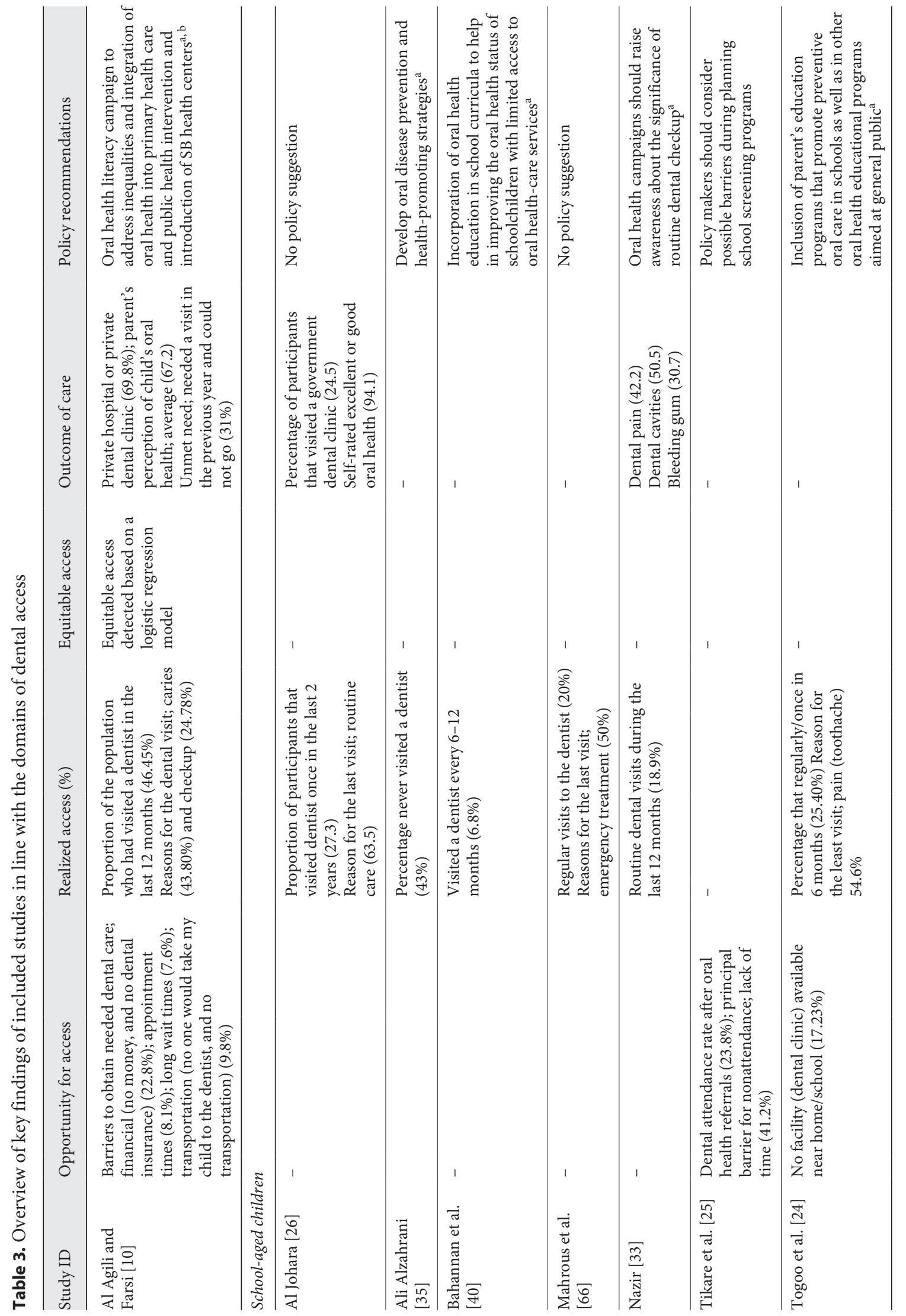




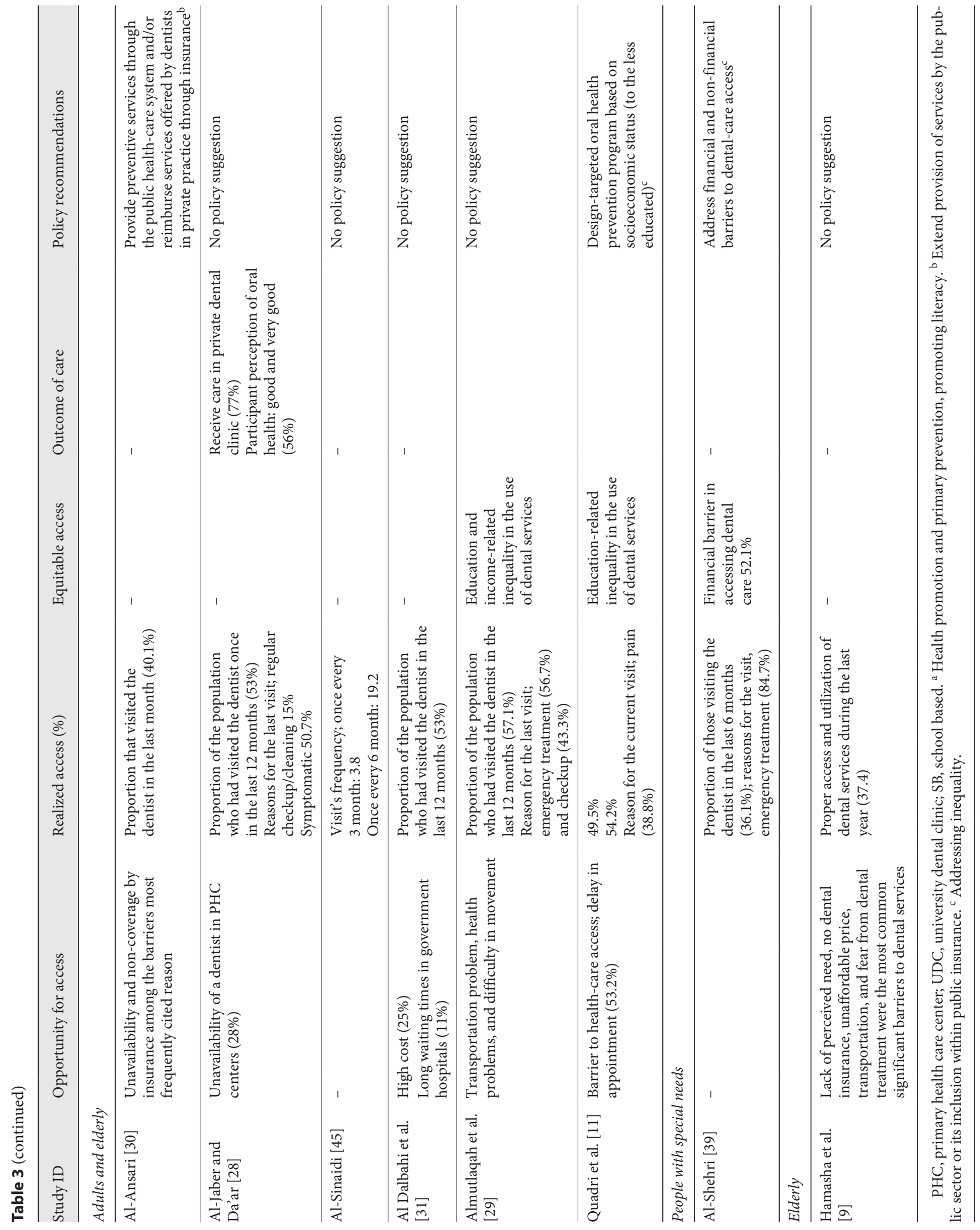


cess to oral health care compared to people with more financial resources [10,31].

Factors such as a low level of education and low income are perceived as barriers to accessing dental care. Parents' education was a major factor limiting utilization of dental care, especially for very young children [10]. Parents with higher levels of education were more likely to have regular oral health-care visits [11]. Mothers' level of education was more important than fathers' level of education in terms of children's visits to the dentist because mothers typically influence oral care and general health more than fathers [41].

Parents and guardians also had access to education and intervention programs through the children's school and teachers [42]. Schools can also support a healthy environment for children by providing guidelines on recommended hygiene practices and limit the sugary food and drink available in schools [43].

\section{Outcomes of Care}

Measuring the outcomes of healthcare is a complementary approach to measurements to increase accessibility (Table 3) [15]. Oral health studies use different indicators to measure oral health status outcomes such as dental caries and periodontal issues [20]. High dental caries, bad oral hygiene, and gingivitis are major oral health issues among individuals with special needs in Jazan, Saudi Arabia [44] due to unmet treatment needs and limited access to dental care, as well as lower oral health promotion among individuals with special needs [44-46]. Other barriers include dental anxiety and financial barriers [38, $39,47]$. In addition, people with disabilities with impaired mobility had difficulty accessing preventive information on oral health, which impacted their oral health status [48].

More than $60 \%$ of the population in Saudi Arabia is composed of adults and the elderly. However, few studies have been conducted among these groups regarding oral health [49]. However, approximately $92 \%$ of the population between ages 20 and 64 have dental caries, and $26 \%$ have untreated caries [50]. Caries are found to be the most common cause of tooth extraction in the country [49].

\section{Dental Access in the Jazan Region}

In 1985, the DMFT in Jazan was 1.2 [51]. After decades, the rate of dental caries experience of $70 \%$ permanent dentition is as high as $3.5[4,11,52]$. This can be attributed to various factors such as poor oral hygiene practices, excessive consumption of sweets, or low utilization rates of dental services [49]. Dental disease in Jazan is a great challenge that needs to be addressed not only by the affected population but also by the government.

Only one study focused on utilization of dental services in the Jazan region [11]. In that study, 54.2\% reported that their last visit to a dentist was within the previous year [11], while $45.8 \%$ reported that their last visit to a dentist was within a span of 1 year, and $33 \%$ of respondents thought that a dentist should only be visited if they experience pain [11]. This study found that factors like a lack of education on available dental services and bad experiences with dental services are leading causes of dental problems in Jazan [11].

In the Jazan region, school-aged children (60-90\%) are among the most affected population as a result of not receiving frequent dental checkups $[6,14,49]$. Health promotion programs in the region are currently poor [53, 54], which might be attributed to a shortage in staff, particularly pediatric dentists. There are approximately 444 pedodontists in Saudi Arabia, and none in the Jazan region [55]. However, collaboration with dental schools in the region should help to mitigate this shortage by providing referrals to services for children in particular.

Since it is not economically feasible to establish and maintain dental clinics in the rural areas where $17.9 \%$ of the Saudi population lives [51], mobile clinics may be a good option to improve dental health in Jazan. Mobile clinics can provide better awareness and target patients in isolated communities [54]. Innovative modalities such as advanced technology and mobile units can help to overcome dental health-care issues in the region [55].

\section{Discussion}

Research indicates that conventional methods are not adequate to address the increasing population demands for dental healthcare [56]. Children (or their parents) report that they have visited a dentist only when they are in pain. However, this is not ideal dental practice, as regular dental checkups have numerous advantages, such as increasing preventive practices, maintaining good oral health status, and increasing awareness of the benefit of dental services; these checkups are also useful for arranging a follow-up appointment for individuals with good oral conditions [34]. In addition, it allows individuals to avoid potential diseases and maintain good oral and general health.

Dental access is influenced by many factors related to both service provision and service usage [16]. According to Healthy People 2020, barriers such as lack of accessibil-
16

Saudi J Health Syst Res 2022;2:9-19 DOI: $10.1159 / 000517661$
Shubayr/Kruger/Tennant 
ity to dental services, anxiety about dental procedures, lack of awareness of oral health-care needs, and limited finances can limit access to dental care [19]. In Saudi Arabia, dental services provided by the $\mathrm{MOH}$ are free of charge, so financial issues are not a barrier to receive treatment from public facilities; however, there is no system for regular dental visits, and dentists are not required to track patients for monitoring [34, 57]. In addition, issues such as long waiting times and the location of facilities affect access. Government facilities also offer dental care only at a basic level, which leaves complicated procedures such as cosmetic dentistry and dentures and implants, among others, only offered by private facilities [58]. For this reason, many people preferred private clinics [29].

Oral health providers need to improve their knowledge, skills, and confidence in treating vulnerable populations, as well as learn strategies to overcome different barriers so that they can have access to dental care. This assertion is supported by a study conducted in Saudi Arabia [39], who highlighted the need for more training. In addition, there is a need to establish education programs that address oral health promotion and disease prevention among the whole population $[44,46]$.

A shift in dental policy can ease modern health-care systems and replace traditional setups that have been proven to be ineffective [59]. Improvements to these services could be done through consultations that provide direct contact between dentists and patient at specific times [60], as well as improvements in storing and sharing patient data [60]. Improved data collection and storage are important particularly for people located in undeserved or remote areas.

There has been an enormous development in the world with regard to the use of the internet and its applications for health purposes. One example of these improvements is teledentistry, which provides dental services (preventive or diagnostic) by using videoconferences [61]. Teledentistry enables dental providers located many miles away to make a diagnosis and recommend treatment options or referrals [60]. It has proven to be a promising model for oral health care because it overcomes social and geographic boundaries. In Saudi Arabia, one study showed the readiness of dental professionals to be engaged in the teledentistry approaches [62] in order to improve access to dental services in remote areas. Teledentistry is an example of a major change driving the country's initiatives [63]. There is a need for policy makers and stakeholders to consider the use these services in dental clinics. In addition, more education and greater efforts are needed among dental workers to use technology properly [56].

School programs and outreach activities need to be implemented by dental schools and dentists from the $\mathrm{MOH}$; these programs must be measurable, sustainable, and effective. The Ministry of Education has banned food items in school canteens such as candy, chocolate, chips, soda, sports drinks, sweetened beverages, all meat products, and fried foods [64]. However, one study showed that most of the foods offered in the selected boys' public high schools were still energy-dense foods that were high in fat and sugars [64]. Thus, it is important that schools regulate the food offered to students and that they make healthier food choices available in the canteens.

Increasing the number of referrals from physicians to dental professionals can also help in improving the present scenario. Informative sessions for medical personnel on basic oral health problems can help physicians to make appropriate referrals [61], which should be a feature of oral health care in Saudi Arabia. A study found that the health system in Jazan has an inadequate referral system for delivering high-quality health services [12]. However, adopting a referral system in Jazan can make dental care less costly and help the public to access effective oral care solutions. In addition, the establishment of health-care clusters can be considered in order bring together different levels of dental services and offer them to the local population at a regional level. Dental clusters provide several advantages such as supporting the multidisciplinary approach to patient care and a closer collaboration between primary care dental services and other health-care colleagues [65]. These advantages may help overcome the current difficulties patients face in accessing dental care. An online referral management system can facilitate referral pathways within the clusters [65].

\section{Conclusions}

Providing access to dental service is essential, and it is considered to be one of the main strategic goals of Vision 2030 in Saudi Arabia [63]. It is imperative to improve the community's dental health by setting up different initiatives such as teledentistry, dental education in schools, and referral programs from physicians in order to increase marginalized communities' access to afford better dental health care services. 


\section{Acknowledgements}

The authors would like to acknowledge Jazan University, which has supported this study at the University of Western Australia. This support is highly acknowledged and appreciated. The authors would also like to extend their sincere gratitude to the school authorities at the University of Western Australia for their continuous support throughout the research.

\section{Statement of Ethics}

Only openly accessible, nonidentifiable data and information were used for this research, and therefore, ethics approval was not necessary.

\section{References}

1 Topaloglu-Ak A, Eden E, Frencken JE. Managing dental caries in children in Turkey: a discussion paper. BMC Oral Health. 2009 Dec;9(1):1-8.

2 Farooqi FA, Khabeer A, Moheet IA, Khan SQ, Farooq I, ArRejaie AS. Prevalence of dental caries in primary and permanent teeth and its relation with tooth brushing habits among schoolchildren in Eastern Saudi Arabia. Saudi Med J. 2015 Jun;36(6):737-42.

3 Duncan L, Bonner A. Effects of income and dental insurance coverage on need for dental care in Canada. J Can Dent Assoc. 2014 Jan 1; 80:e6.

4 Al Agili DE. A systematic review of population-based dental caries studies among children in Saudi Arabia. Saudi Dent J. 2013 Jan 1;25(1):3-11.

5 Al-Malik MI, Rehbini YA. Prevalence of dental caries, severity, and pattern in age 6 to 7 -year-old children in a selected community in Saudi Arabia. J Contemp Dent Pract. 2006 May 1;7(2):46-54.

6 Ministry of Health. Oral and Dental Diseases - Facts on Oral and Dental Health [Internet]. [cited 2021 May 7]. Available from: https:// www.moh.gov.sa/en/HealthAwareness/EducationalContent/Diseases/DiseasesOralanddental/Pages/OralandDentalHealth.aspx.

7 Chapple IL, Genco R. Diabetes and periodontal diseases: consensus report of the joint EFP/ AAP workshop on periodontitis and systemic diseases. J Periodontol. 2013 Apr;84:S106-12.

8 Ide M, Papapanou PN. Epidemiology of association between maternal periodontal disease and adverse pregnancy outcomes: systematic review. J Periodontol. 2013 Apr;84: S181-94.M

9 Hamasha AA, Aldosari MN, Alturki AM, Aljohani SA, Aljabali IF, Alotibi RF. Barrier to access and dental care utilization behavior with related independent variables in the elderly population of Saudi Arabia. J Int Soc Prev Community Dent. 2019 Jul;9(4):349.

\section{Conflict of Interest Statement}

The author declare that there is no conflict of interest.

\section{Funding Sources}

The authors did not receive any funding.

\section{Author Contributions}

All the authors designed and implemented the study. M.S. completed the data collection and data entry. All the authors contributed equally in writing and proofreading the manuscript.
10 Al Agili DE, Farsi NJ. Need for dental care drives utilisation of dental services among children in Saudi Arabia. Int Dent J. 2020 Jun 1;70(3):183-92.

11 Quadri FA, Jafari FA, Albeshri AT, Zailai AM. Factors influencing patients' utilization of dental health service in Jazan, Kingdom of Saudi Arabia. Int J Clin Ped Dent. 2018 Jan; 11(1):29.

12 Gosadi IM. Case report of patient experience influenced by inadequate interactions between primary, secondary, and tertiary healthcare services in the south of Saudi Arabia. Clin Case Rep. 2020 Feb;8(2):299-304.

13 Quadri FA, Hendriyani H, Pramono A, Jafer M. Knowledge, attitudes and practices of sweet food and beverage consumption and its association with dental caries among schoolchildren in Jazan, Saudi Arabia. East Mediterr Health J. 2015;21(6):403-11.

14 Shubayr MA, Kruger E, Tennant M. Assessment of dental healthcare services and workforce in the Jazan Region, Saudi Arabia. Saudi J Oral Dent Res. 2021;6(1):81-7.

15 Millman M. Access to Health Care in America Committee on Monitoring Access to Personal Health Care Services, Institute of Medicine [Internet]. USA: National Academies Press; 1993. [cited 2021 May 7]. Available from: https://www.ncbi.nlm.nih.gov/books/ NBK235888/.

16 Xu K, Saksena P, Evans DB. Health financing and access to effective interventions. World Health Report (2010) [Internet]; 2010. Background Paper, 8. [cited 2021 May 7]. Available from: https://www.who.int/healthsystems/topics/financing/healthreport/8Accesstocare. pdf?ua $=1$.

17 Gambhir RS, Brar P, Singh G, Sofat A, Kakar $H$. Utilization of dental care: an Indian outlook. J Nat Sci Biol Med. 2013 Jul;4(2):292.

18 Harris RV. Operationalisation of the construct of access to dental care: a position paper and proposed conceptual definitions. Community Dent Health. 2013 Jun 1;30(2):94-101.
19 Healthy People. Oral Health [Internet]. [cited 2021 May 7]. Available from: https://www. healthypeople.gov/2020/topics-objectives/ topic/oral-health.

20 Hummel R, Bruers J, van der Galiën O, van der Sanden W, van der Heijden G. Outcome measures for oral health based on clinical assessments and claims data: feasibility evaluation in practice. BMC Oral Health. 2017 Dec; $17(1): 125-8$

21 Shubayr MA, Alexander LR, Tabatabai MA, Alagili DE. Knowledge, attitude and practice of oral health promotion among oral health providers in Kingdom of Saudi Arabia. J Contemp Dental Prac. 2019 Feb 1;20(2):231-8.

22 Arksey H, O’Malley L. Scoping studies: towards a methodological framework. Int J Soc Res Methodol. 2005 Feb 1;8(1):19-32.

23 Andersen RM, Davidson PL, Baumeister SE. Improving access to care in America. Changing the US health care system: key issues in health services policy and management. 3rd ed. San Francisco: Jossey-Bass; 2007. p. 1-3.

24 Togoo R, Yaseen S, Zakirulla M, VSN, Al Zamzami M. Oral hygiene knowledge and practices among school children in a rural area of southern Saudi Arabia. Int J Contemp Dent. 2012;3(1):57-62.

25 Tikare S, AlQahtani NA, Eroje AB, AlQahtani $\mathrm{KM}$, Assiri JA, AlAmri MH. Effectiveness of school oral health screening and factors affecting dental attendance among female primary school children in Saudi Arabia. J Adv Oral Res. 2017 May;8(1-2):63-8.

$26 \mathrm{Al}$ Johara A. Factors affecting utilization of dental health services and satisfaction among adolescent females in Riyadh City. Saudi Dental J. 2010 Jan;22(1):19-25.

27 M Orfali DS, S Aldossary DM. Utilization of dental services in Saudi Arabia: a review of the associated factors. Saudi J Oral Dent Res. 2020 Mar 25;5(3):147-9. 
28 Al-Jaber A, Da'ar OB. Primary health care centers, extent of challenges and demand for oral health care in Riyadh, Saudi Arabia. BMC Health Serv Res. 2016 Dec;16(1):628-8.

29 Almutlaqah MA, Baseer MA, Ingle NA, Assery MK, Al Khadhari MA. Factors affecting access to oral health care among adults in Abha City, Saudi Arabia. J Int Soc Prevent Com Dent. 2018 Sep;8(5):431.

$30 \mathrm{Al}$-Ansari A. Awareness, utilization, and determinants of using oral diseases prevention methods among Saudi adults: a clinic-based pilot study. Int J Health Sci. 2016 Jan;10(1):77.

31 Al Dalbahi F, Abdulrahman L, Ansari S. Challenges faced by the general public in receiving dental care in Riyadh City, Saudi Arabia: a survey-based study. Donnish J Dentistry Oral Hyg. 2019 May;5(2):40-8.

32 El Bcheraoui C, Tuffaha M, Daoud F, Kravitz $\mathrm{H}$, AlMazroa MA, Al Saeedi M, et al. Use of dental clinics and oral hygiene practices in the Kingdom of Saudi Arabia. Int Dent J. 2016 Apr;66(2):99-104.

33 Nazir MA. Predictors of routine dental checkup among male adolescents in Saudi Arabia. Acta Stomatol Croat. 2019 Sep 26;53(3):25563.

34 AlHumaid J, El Tantawi M, AlAgl A, Kayal S, Al Suwaiyan Z, Al-Ansari A. Dental visit patterns and oral health outcomes in Saudi children. Saudi J Med Med Sci. 2018 May;6(2):89.

35 Alzahrani AA. The oral health status and attitudes of Saudi adolescent male students in Albaha province: a cross-sectional study. Adv Dent Oral Heal. 2018 Nov;10(1):35-41.

36 Camargo MB, Barros AJ, Frazão P, Matijasevich A, Santos IS, Peres MA, et al. Predictors of dental visits for routine check-ups and for the resolution of problems among preschool children. Rev Saude Publica. 2012 Feb;46(1): 87-97.

37 Alumran A, Almulhim L, Almolhim B, Bakodah S, Aldossary H, Alrayes SA. Are dental care providers in Saudi Arabia prepared to treat patients with special needs? J Multi Health. 2019;12:281.

38 Aljabri MK, Gadibalban IZ, Kalboush AM, Sadek HS, Abed HH. Barriers to special care patients with mental illness receiving oral healthcare: a cross sectional study in the Holy City of Makkah, Saudi Arabia. Saudi Med J. 2018 Apr;39(4):419.

39 AL-Shehri SA. Access to dental care for persons with disabilities in Saudi Arabia (Caregivers' perspective). J Dis Oral Health. 2012; 13(2):51.

40 Bahannan SA, Eltelety SM, Hassan MH, Ibrahim SS, Amer HA, El Meligy OA, et al. Oral and dental health status among adolescents with limited access to dental care services in Jeddah. Dent J. 2018 Jun;6(2):15.
41 Lee CY, Ting CC, Wu JH, Lee KT, Chen HS, Chang YY. Dental visiting behaviours among primary schoolchildren: application of the health belief model. Int J Dent Hyg. 2018 May; 16(2):e88-95.

42 Halawany HS, Al Badr A, Al Sadhan S, Al Balkhi M, Al-Maflehi N, Abraham NB, et al. Effectiveness of oral health education intervention among female primary school children in Riyadh, Saudi Arabia. Saudi Dent J. 2018 Jul;30(3):190-6.

43 Amin TT, Al-Abad BM. Oral hygiene practices, dental knowledge, dietary habits and their relation to caries among male primary school children in Al Hassa, Saudi Arabia. Int J Dent Hyg. 2008 Nov;6(4):361-70.

44 Darout IA, Tobaigy FM, Al Moaleem MM, Ahmad M, Shubayr MA, Kinani HM. Knowledge and oral health related behavior among visually impaired subjects in Jazan region, Kingdom of Saudi Arabia. J Dent Oral Hyg. 2015 Mar 31;7(3):33-9.

45 Al-Sinaidi AA. Oral hygiene practices and periodontal health status of visually impaired Saudi adults in Riyadh, Saudi Arabia. Pakistan Oral Dent J. 2013 Apr;33(1):82-6.

46 Alkahtani FH, Baseer MA, Ingle NA, Assery MK, Al Sanea JA, AlSaffan AD, et al. Oral health status, treatment needs and oral health related quality of life among hearing impaired adults in Riyadh City, Saudi Arabia. J Contemp Dent Pract. 2019 Jun;20(6):743.

47 Ho HD, Satur J, Meldrum R. Perceptions of oral health by those living with mental illnesses in the Victorian Community: the consumer's perspective. Int J Dent Hyg. 2018 May; 16(2):e10-6.

48 Griffiths J. Accessible to all: removing barriers to good oral health. Vital. 2006 Dec;3(4):3941.

49 Al-Ansari A. Prevalence, severity, and secular trends of dental caries among various Saudi populations: a literature review. Saudi J Med Med Sci. 2014 Sep;2(3):142.

50 National Institute of Dental and Craniofacial Research. Dental caries (tooth decay) in adults (age 20 to 64) [Internet]. National Health and Nutrition Examination Survey; 2004 [cited 2021 May 7]. Available from: https: //www.nidcr.nih.gov/research/datastatistics/dental-caries/adults.

51 United Nations Human Settlements Programme. Saudi Arabia Urban Issues: United Nations Human Settlements Programme. [cited $202127 \mathrm{Jan}$ ]. Available from: https:// unhabitat.org/saudi-arabia-urban-issues.

52 Quadri MFA, Shubayr MA, Hattan AH, Wafi SA, Jafer AH. Oral hygiene practices among Saudi Arabian children and its relation to their dental caries status. Int J Dent. 2018 Apr; 2018:3234970.

53 Milaat W, Bani I, Aqeely H, Makeen A, Salih A, Alnagaar M. Jazan Health needs assessment: a key informant approach. J Public Health Med. 2007;6:105-10.
54 Ganavadiya R, Chandrashekar B, Goel P, Hongal S, Jain M. Mobile and portable dental services catering to the basic oral health needs of the underserved population in developing countries: a proposed model. Ann Med Health Sci Res. 2014;4(3):293-304.

55 AlBaker AA, Al-Ruthia YSH, AlShehri M, Alshuwairikh S. The characteristics and distribution of dentist workforce in Saudi Arabia: a descriptive cross-sectional study. Saudi Pharm J. 2017 Dec 1;25(8):1208-16.

56 Aboalshamat KT. Awareness of, beliefs about, practices of, and barriers to teledentistry among dental students and the implications for Saudi Arabia Vision 2030 and coronavirus pandemic. J Int Soc Prev Community Dent. 2020 Jul;10(4):431.

57 Baghdadi ZD. Managing dental caries in children in Saudi Arabia. Int Dent J. 2011 Apr; 61(2):101-8.

58 Alshahrani AM, Raheel SA. Health-care system and accessibility of dental services in Kingdom of Saudi Arabia: an update. J Int Oral Health. 2016 Aug;8(8):883-7.

59 Alsharif AT. Georeferencing of current dental service locations to population census data: identification of underserved areas in $\mathrm{Al} \mathrm{Ma}$ dina, Saudi Arabia. SAGE Open. 2020 Dec; 10(4):1-8.

60 Fricton J, Chen H. Using teledentistry to improve access to dental care for the underserved. Dent Clin North Am. 2009 Jul;53(3): $537-48$

61 Khemka S, Baliga S, Thosar N. Approaches to improve access to dental care services. Int Dent Med J Adav Res. 2015 April;1(1):1-4.

62 Al-Khalifa KS, AlSheikh R. Teledentistry awareness among dental professionals in Saudi Arabia. PLoS One. 2020 Oct;15(10): e0240825-13.

63 Council of Economic and Development Affairs. KSA Vision 2030: strategic objectives and vision realization programs. [Internet]. Riyadh; 2016. [cited 2021 May 7]. Available from: https://vro.moenergy.gov.sa/Arabic/ Pages/default.aspx.

64 Aldubayan K, Murimi M. Compliance with school nutrition policy in Saudi Arabia: a quantitative study. East Mediterr Health J. 2019 Apr;25(4):230-8.

65 Shih YT, Liu L. Use of claims data for cost and cost-effectiveness research. Semin Radiat Oncol. 2019 Oct;29(4):348-53.

66 Mahrous MS, Bhayat A, Hifnawy T, Bakeer H, Ahmad MS. Can the prevalence of dental caries be used as an indicator of the quality of dental services? A cross-sectional study among children in Almadinah Almunawwarah. KSA. J Taibah Univ Med Sci. 2016 Feb; 11(1):41-5. 